\title{
Contents, Vol. 10, 1995
}

\section{No.1}

Clinical Significance of Creatine Kinase Iso-1

enzymes for Fetal Asphyxia in Women at Labor Andronikou, S.; Bairaktari, E.; Vasiliadou, A.D.; Stefos, Th.; Lolis, D.; Tsolas, O.; Lapatsanis, P.D.

Pharmacokinetics of Interferon-Alpha in Preg- 7 nant Women and Fetoplacental Passage Pons, J.-C; Lebon, P.; Frydman, R.; Delfraissy, J.-F. Measurement of Fetal Plasma Levels of Gluta11

thione S-Transferase Bi as an Indicator of Damage to the Liver Caused by Hypoxia in utero Holt, D.E.; Howie, A.F.; Beckett, G.J.; Hurley, R.; Harvey, D.

Prediction of Second Trimester Intrauterine 17

Growth Retardation and Fetal Death in a Discordant Twin by First Trimester Measurements. Case Report and Review of the Literature Tadmor, O.; Nitzan, M.; Rabinowitz, R.;

Skomorovsky, Y.; Aboulafia, Y.; Diamant, Y.Z.

Pregnancy Complicated by Ebstein’s Anomaly: 22 Oxygen Administration to Mother for Chronic Fetal Hypoxemia. A Therapeutic Case Report Negishi, H.; Yamada, H.; Okuyama, K.; Makinoda, S.; Fujimoto, S.

Twin-to-Twin Transfusion Syndrome: Selective 26 Feticide by Embolization of the Hydropic Fetus Dommergues, M; Mandelbrot, L.; Delezoide, A.-L.; Aubry, M.-C; Fermont, L.; CaputoMahieu, D.; Dumez, Y.

Selective Feticide in Twin Transfusion Syn- 32

drome Using Ultrasound-Guided Insertion of

Thrombogenic Coils

Bebbington, M.W.; Wilson, R.D.; Machan, L.;

VVittmann, B.K.

Markedly Elevated Alpha-Fetoprotein and Posi- 37 tive Acetylcholinesterase in Amniotic Fluid from a Pregnancy Affected with Dystrophic Epidermo-lysis bullosa Drugan, A.; Vadas, A.; Sujov, P.; Gershoni-Baruch, R.

Fetal in situ Cardiovascular and Pulmonary Mor- 41 phology of Vascular Ring due to Left Aortic Arch and Right Ductus arteriosus in Rats Momma, K.; Ando, M.

Fetomatemal Hemorrhage: Diagnostic Problems. 48 Three Case Reports

D’Ercole, C; Boubli, L.; Chagnon, C; Nicoloso, E.; Leclaire, M.; Cravello, L.; Blanc, B.

Associated Malformations and Chromosomal 52

Defects in Congenital Diaphragmatic Hernia Bollmann, R.; Kalache, K.; Mau, H.; Chaoui, R.;

Tennstedt, C.

Ultrastructural Alterations of the Amniocytes in 602 Patients with Rubella during the First

Trimester of Pregnancy Straussberg, R.; Amir, J.; Harel, L.; Djaldetti, M.

Rapid Determination of Fetal Sex in Coelomic 66

and Amniotic Fluid by Fluorescence in situ

Hybridisation 
Pandya, P.P.; Cardy, D.L.N; Jauniaux, E.; Campbell, S.;

Nicolaides, K.H.

Announcement

10

III

No. 2

In utero Fetal Muscle Biopsy Alters Diagnosis 71

and Carrier Risks in Duchenne and Becker Muscular Dystrophy

Evans, M.I.; Krivchenia, E.L.; Johnson, M.P.; Quintero, R.A.; King, M.; Pegoraro, E.; Hoffman, E.P.

Very Low Maternal Serum Unconjugated Estriol 76 and Prenatal Diagnosis of Steroid Sulfatase Deficiency

David, M.; Israel, N.; Merksamer, R.; Bar-Nizan, N.; Borochowitz, Z.; Bar-El, H.; Yehudai, I.;

Dar, $\mathrm{H}$.

Needle Embryofetoscopy and Early Prenatal 81

Diagnosis

Reece, E.A.; Homko, C.J.; Wiznitzer, A.; Goldstein, I.

Fetal Responses to Inadvertent Contact with the 83 Needle during Amniocentesis Petrikovsky,

B.M.; Kaplan, G.P.

Fetal Serum Erythropoietin in Twin Pregnancies 86 with Discordant Growth. A Clue for the

Prenatal Diagnosis of Monochorionic Twins with Vascular Communications

Lemery, D.R.; Santolaya-Forgas, J.; Serre, A.F.; Besse, G.H.; Jacquetin, B.

Midtrimester Thoracoamniotic Shunting for the 92 Treatment of Fetal Hydrops Morrow, R.J.;

Macphail, S.; Johnson, J.-A.; Ryan, G; Farine, D.; Knox Ritchie, J.W.

Predictive Value of Pleural Effusions in Fetal 95

Hydrops

Smoleniec, J.; James, D.

Survival in Non-Immune Hydrops fetalis with- 101 out Malformation or Chromosomal

Abnormalities after Invasive Treatment Ayida, G.A.; Soothill, P.W.; Rodeck, C.H.

Ominous Normalization of Middle Cerebral 106

Artery Flow Velocity Waveforms Preceding Fetal Death: Case Report

Chitrit, Y.; Zorn, B.; Filidori, M.; Bucourt, M.; Chasseray, J.E.; Caubel, P.

Are 'Notched' Uterine Arterial Waveforms of 111

Prognostic Value for Hypertensive and Growth

Disorders of Pregnancy?

Mires, G.J.; Christie, A.D.; Leslie, J.; Lowe, E.;

Patel, N.B.; Howie, P.W.

Iatrogenic Gastroschisis Decreases Pulmonary 119 Hypoplasia in an Ovine Congenital

Diaphragmatic Hernia Model

Montgomery, L.D.; Belfort, MA.; Saade, G.R.; Wycke Baker, B.; Pokorny, W.; Minifee, P.;

Langston, C; Jevon, G.; Van den Veyver, I.; Robie, D.; Longmire, S.; Palacios Q.; Moise, K.J., Jr.

In utero Surfactant Administration to Preterm 127 Human Fetuses using Endoscopy Petrikovsky, B.M.; Lysikiewicz, A.; Markin, L.B.; Slomko, Z.

Fetal Hepatosplenomegaly Associated with Tran- 131 sient Myeloproliferative Disorder in Trisomy 21 Macones, G.A.; Johnson, A.; Tilley, D.; Wade, R.; Wapner, R. 
A Case of Nondiabetic Macrosomia with Simp- 134 son-Golabi-Behmel Syndrome: Antenatal Sono-graphic Findings

Yamashita, H.; Yasuhi, I.; Ishimaru, T.; Matsumoto, T.; Yamabe, T.

Comment on the Article by J. Wisser et al.: 139

Neonatal Hemochromatosis: A Rare Cause of Nonimmune Hydrops fetalis and Fetal Anemia.

[Fetal Diagn Ther 1993;8:273-278] Knisley, A.S.

140

Reply

Wisser, J.

IV

Contents

No. 3

Effect of Delivery on Fetal Erythropoietin and 141 Blood Gases in Pregnancies with Maternal Diabetes mellitus Salvesen, D.R.; Brudenell, M.J.; Nicolaides, K.H.

Helping Parents to Grieve after Second Trimes- 147

ter Termination of Pregnancy for Fetopathic

Reasons

Lorenzen, J.; Holzgreve, W.

Current Maternal Age Recommendations for 157

Prenatal Diagnosis: A Reappraisal Using the Expected Utility Theory Sicherman, N.; Bombard, A.T.; Rappoport, P.

Endoscopically Assisted, Ultrasound-Guided

167

Fetal Muscle Biopsy

Evans, M.I.; Quintero, R.A.; King, M.; Qureshi, F.; Johnson, M.P.

Fetal Blood Sampling and Fetal Thrombo- 173

cytopenia

Weiner, C.P.

Single-Needle Insertion: An Alternative Tech- 178

nique for Early Second-Trimester Genetic Twin

Amniocentesis

van Vugt, J.M.G.; Nieuwint, A.; van Geijn, H.P.

Role of Ultrasonography in Pregnancies with

Marker Chromosome Aneuploidy Hume, R.F., Jr.; Drugan, A.; Ebrahim, S.A.D.; Johnson, M.P.;

Isada, N.B.; Reichler, A.; Evans, M.I.

Second Trimester Selective Termination of a186

Twin with Ruptured Membranes: Elimination of Fluid Leakage and Preservation of Pregnancy

Dorfman, S.A.; Robins, R.M.; Jewell, W.H.; St. Louis, L.; Evans, M.I.

Fetal Tissue Dosages of Retinoids. Experimental 189 Study Concerning a Case of Isotretinoin

(Roaccutan ${ }^{\circledR}$ ) Administration and Pregnancy Benifla, J.L.; Ville, Y.; Imbert, M.C.; Frydman, R.;

Thomas, A.; Pons, J.C.

Cordocentesis for Rapid Karyotype: 421 Consec- 192

utive Cases

Donner, C; Rypens, F.; Paquet, V.; Cohen, E.;

Delneste, D.; van Regemorter, N.; Vamos, E.; Avni, F.;

Rodesch, F. 
Transient Ascites Associated with a Fetal Ovar- 200 ian Cyst. Case Report Degani, S.;

Lewinsky, R.M.

Fetal-Maternal Hydrops Syndrome in Human 204

Parvovirus Infection

Ville, Y.; de Gayffier, A.; Brivet, F.; Leruez, M.;

Marchal, P.; Morinet, F.; Troalen, F.; Fernandez, H.;

Frydman, R.

A Case of Fetal Bradycardia and Sinusoid-Like 207 Fetal Heart Rate Pattern Associated with Maternal Hypothermia

Tanaka, M.; Ikeda, T.; Suzuki, T.; Yakubo, K.; Fukuiya, T.

Book Review 210

No. 4

Fetal Biometry 215

Growth Charts for Practical Use in Feto-

pathology and Antenatal Ultrasonography

Anne-Marie Guihard-Costa, Jeanne-Claudie Larroche,

Paris

in collaboration with: Pierre Droullé, Nancy;

Françoise Narcy, Paris

No. 5

Fetal Haematological Response to Intra-Uterine 279 Infection in Preterm Prelabour

Amniorrhexis Carroll, S.G.; Nicolaides, K.H.

Impact of Abnormal Second-Trimester Maternal 286 Serum Single, Double, and Triple

Screening on Patient Choices about Prenatal Diagnosis Lowry, D.L.B.; Campbell, S.A.;

Krivchenia, E.L.; Dvorin, E.; Duquette, D.; Evans, M.I.

Maternal Assessment in the Prediction of Intra- 290 uterine Infection in Preterm Prelabor

Amniorrhexis

Carroll, S.G.; Papaioannou, S.; Davies, E.T.; Nicolaides, K.H.

$\mathrm{V}$

Fetal Serum Ferritin and Cobalamin in Red 297

Blood Cell Isoimmunisation Abbas, A.; Nicolaides, K.

Effect of Betamethasone on the Fetal Heart Rate 301 Pattern Assessed by Computerized Cardiotocography in Normal Twin Pregnancies Ville, Y.; Vincent, Y.; Tordjman, N; Hue, M.V.;

Fernandez, H.; Frydman, R.

Utility of Fetal Intraperitoneal Saline Infusion 307 in the Prenatal Evaluation of Diaphragmatic

Hernia

Meagher, S.; Fisk, N.; Boogert, A.

Sonographic Prenatal Diagnosis of Ambiguous 311

Genitalia

Sivan, E.; Koch, S.; Reece, E.A.

Changes in Blood Flow Velocity Waveforms

315

following Fetal Blood Sampling Zoppini, C; Brioschi, D.; Tassis, B.; Zuliani, G.; Kustermann, A.; Nicolini, U.

A New Method for Sampling Maternal Blood in 322 the Placental Intervillous Space Camelo, J.S., Jr.; Martinez, F.E.; Jorge, S.M.; de Sala, M.M. 
A Non-Human Primate Model for the in utero 326 Chronic Catheterization of the Umbilical Vein. A Preliminary Report

Lemery, D.J.; Santolaya-Forgas, J.; Wilson, L., Jr.; Bieniarz, A.; Warsof, S.L.

Dandy-Walker Malformation in a Fetus with333

Pentasomy X (49, XXXXX) Prenatally Diagnosed by Fluorescence in situ Hybridization

Technique

Myles, T.D.; Burd, L.; Font, G.; McCorquodale, M.M.; McCorquodale, D.J.

How to Deal with a Rare Entity: The Coexistence 337

of a Complete Mole and a Healthy Egg in a Twin

Pregnancy?

Garbin, O.; Favre, R.; Weber, P.; Arbogast, E.;

Gasser, B.

Severe Urethral Obstruction Diagnosed at 14

Weeks' Gestation: Variability of Outcome with and without Drainage Mac Mahon, R.A.; Renou, P.M.; Shekleton, P.A.; Paterson, P.J.

No. 6

Fetal Mild Hydronephrosis and Chromosomal 349 Defects: Relation to Maternal Age and

Gestation Snijders, R.J.M.; Sebire, N.J.; Faria, ML; Patel, F.; Nicolaides, K.H.

Maternal Age and Gestational Age-Specific Risk 356

for Chromosomal Defects

Snijders, R.J.M.; Sebire N.J.; Nicolaides, K.H.

Maternal Age-Dependent and Sex-Related 368

Changes of Gestational Serum Alpha-Fetoprotein Szabó, M.; Veress, L.; Münnich, Á.; Papp, Z.

Management of Platelet and RhD Maternal 373

Immunizations by PCR Phenotypings after Early

Amniocentesis

Sagot, P.; Bonneville, F.; Bignon, J.D.; Cesbron, A.;

Boog, G.; Muller, JY.

Cardiac Defects in 1 st-Trimester Fetuses with 381

Trisomy 18

Hyett, J.A.; Moscoso, G.; Nicolaides, K.H.

Prenatal Diagnosis of a (X;X) Translocation by 387 Fluorescence in situ Hybridization and Laser

Scanning Image Cytometry Tachdjian, G.; Cacheux, V.; Kiefer, H; Druart, L.; Lapierre, J.-M.;

Oury, J.-F.; Blot, P.; Metezeau, P.

Congenital Diaphragmatic Hernia: Prognosis and 393

Prenatal Detection

Pfleghaar, KM; Wapner, R.J.; Kuhlman, K.A.;

Spitzer, A.R.

Antenatal Diagnosis and Surgical Management 400 of Congenital Cystic Adenomatoid

Malformation of the Lung

Taguchi, T.; Suita, S.; Yamanouchi, T.; Nagano, M.; Satoh, S.; Koyanagi, T.; Nakano, H.

Transabdominal Amnioinfusion in Preterm 408

Pregnancies Complicated by Fetal Growth Restriction, Oligohydramnios and Umbilical Cord

Compression. A Report of 4 Cases Sarno, A.P.; Polzin, W.J.; Feinstein, S.J.; Maslow, A.

Author Index Vol. 10, 1995415

Subject Index Vol. 10, 1995417 
VI

Contents 